\section{STYLISTICS OF UKRAINIAN \\ FINE ART, ARCHITECTURE AND DESIGN IN THE SECOND \\ HALF XIX - EARLY XXI CENTURIES' PERIOD}

Olga Shkolna, https://orcid.org/0000-0002-7245-6010 Doctor in Art Studies, Professor,

Borys Grynchenko

Kyiv University, Kyiv, Ukraine dushaorchidei@ukr.net

Olga Sosik, https://orcid.org/0000-0002-2450-1235 PhD in Art Studies, Borys Grynchenko

Kyiv University Kyiv, Ukraine olhasosik@gmail.com

Alla Buigasheva, https://orcid.org/0000-0002-9644-1657

People's Artist of Ukraine, Professor, Borys Grynchenko

Kyiv University, Kyiv, Ukraine ABB10@i.ua

\section{СТИЛІСТИКА УКРАЇНСЬКОГО ОБРАЗОТВОРЧОГО МИСТЕЦТВА, АРХІТЕКТУРИ ТА ДИЗАЙНУ ДРУГОÏ ПОЛОВИНИ XIX - ПОЧАТКУ XXI СТОЛІТЬ}

\section{Ольга Школьна,}

https://orcid.org/0000-0002-7245-6010 доктор мистецтвознавства, професор, Київський університет імені Бориса Грінченка,

Київ, Україна

dushaorchidei@ukr.net

\section{Ольга Сосік,}

https://orcid.org/0000-0002-2450-1235

кандидат мистецтвознавства,

Київський університет

імені Бориса Грінченка,

Київ, Україна

olhasosik@gmail.com

\section{Алла Буйгашева,}

https://orcid.org/0000-0002-9644-1657

народний художник України, профресор, Київський університет

імені Бориса Грінченка,

Київ, Україна

ABB10@i.ua

\section{Abstract}

The aim is to explore the key concepts of stylistics of Ukrainian fine arts, architecture and various types of design of the second half of the XIX - early XXI centuries in the relationship of individual fields of knowledge. Research methods - hermeneutic, axiological, historical-ge-
Анотація

Мета - дослідити ключові поняття стилістики українського образотворчого мистецтва, зодчества та різних видів дизайну другої половини XIX - поч. XXI ст. у взаємозв'язках окремих галузей знань. Методи дослідження - герменевтичний, аксіологічний, 
netic, historical-chronological, comparative, culturological, formal-stylistic, art analysis. The selected tools allow you to compare the stylistic features of different types of design (industrial, graphic, clothing, environment), fine arts and architecture. A novelty is an overview of evolutionary processes in terms of styles in painting, graphics, architecture, various types of design activities (in particular, environmental design, industrial, graphic, clothing). The points of intersection of the conceptual and categorical sphere of the indicated branches of creativity are outlined, both common and different tendencies concerning the identification of stylistic features are observed. Conclusions. The differences of separate branches of knowledge of artistic creativity and common features of some types of design-designing, -construction, -modeling, art technologies bordering on graphic art and painting (graphic design, partly industrial design), architecture (environmental design and partly industrial design) are traced.

Since the era of modernism, art deco, avant-garde, constructivism, functionalism, Stalin's empire, which affected all forms of artistic activity, in the late twentieth - early twenty-first century established the classic, minimalism, high-tech, fusion, low-tech, shabby chic, provence, glamour, some oriental stylizations in the interior associated with architecture. Instead, clothing design, in addition to the classics, over the past few decades has creatively adapted the sports-classic style, manga, country, western, boho, military, glamour and etc. over the past few decades.

If the shapes of the silhouettes of the cut look at the general tendencies of industrial design, the drawings of fabrics partially appeal to the visions of graphic design, which are related to the tendencies of fine arts - tendencies of modernism, avant-garde, postmodernism. Namely, they tend to functionalism, constructivism, boychukism, art deco, socialist realism, Stalinist empire, Ukrainian soviet empire, neo-functionalism, neo-primitivism, neo-folk style, polystylism, glamour. історико-генетичний, історико-хронологічний, компаративний, культурологічний, формально-стилістичний, мистецтвознавчого аналізу. Обраний інструментарій дозволяє здійснити порівняння стилістичних ознак різних видів дизайну (промислового, графічного, одягу, середовища), образотворчого мистецтва та архітектури. Новизну складає огляд еволюційних процесів щодо стилів у живописі, графіці, зодчестві, різноманітних видів дизайнерської діяльності (зокрема, дизайну середовища, промислового, графічного, одягу). Окреслено точки перетину понятійно-категоріальної сфери означених галузей творчості, унаочнено як спільні, так і відмінні тенденції щодо виявлення стилістичних ознак. Висновки. Простежено відмінності окремих галузей знань художньої творчості та спільні риси деяких видів дизайн-проєктування, -конструювання, - моделювання, мистецьких технологій, котрі межують з графічним мистецтвом і живописом (графічний дизайн, частково промисловий дизайн), архітектурою (дизайн середовища і частково промисловий дизайн).

Починаючи з доби модерну, ар деко, авангарду, конструктивізму, функціоналізму, сталінського ампіру, що позначалися на всіх формах художньої діяльності, наприкінці XX - на початку XXI ст. утвердилися класика, мінімалізм, хай-тек, ф'южн, лоутек, шеббі-шик, прованс, гламур, окремі орієнтальні стилізації в інтер'єрі, пов'язаному з архітектурою. Натомість дизайн одягу, окрім класики, упродовж кількох останніх десятиліть творчо адаптував спортивно-класичний стиль, манга, кантрі, вестерн, бохо, мілітарі, гламур тощо. Якщо форми силуетів крою при цьому орієнтуються на загальні тенденції промислового дизайну, то рисунки тканин частково апелюють до візій графічного дизайну, котрі споріднені з тенденціями образотворчого мистецтва - модернізму, авангардизму, постмодернізму. А саме тяжіють до функціоналізму, конструктивізму, бойчукізму, ар деко, соцреалізму, сталінського ампіру, українського радянського ампіру, неофункціоналізму, неопримітивізму, неофольклорного стилю, полістилізму, гламуру. 


\section{Keywords: Ключові слова:}

fine art, architecture, industrial, graphic, fashion and interior design, Ukraine, end of XIX - beginning of XXI century.

образотворче мистецтво, архітектура, промисловий, графічний, дизайн одягу та інтер'єру, Україна, кінець XIX - початок XXI століття.

Introduction 1

Recently, discussions have been resumed in the scientific community which matter is the understanding of stylistics evolution within the period from the "-isms" epoque at the XIX century end up to the XXI century beginning. The interest in the issue of individual stylistic trends periodization, trends and established large styles is actualized by the problematics of interdisciplinary coordination and the design stylistic transformations linking issues.

The latter one in some cases adjoins the "style coloring" aspect in decorative, applied and fine arts. At the same time, sometimes and more often it develops, for example, as an interior, in line with the architectural style. In some cases, we observe in the field of fashion design the design shifting to the areas bordering on show business and "philosophical and ideological" trends like nonconformism and glamour, which are completely atypical for the style evolution when speaking about plastic and space-time arts.

This study is purposed to identify the main design styles that interact with fine, decorative and applied art and architecture, with the attempt of their primary classification to determine the connections and differences in the stylistics of Ukrainian fine art, architecture and design of the second half XIX-early XXI century period.

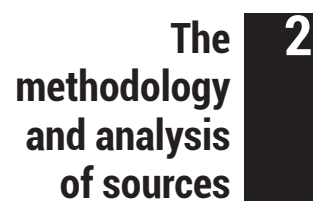

Research methods - on the basis of hermeneutical, axiological, historical-genetic, historical-chronological, comparative, cultural, formal-stylistic and the art history analysis method, clear parallels between these areas of art history are drawn. Outlined are the milestones of art development, design in various industries and architecture, taking into account the opinions of leading theoretical and practical scientists. So, among the most complete publications on styles history and theory, first of all worth mentioning is the first book of the three-volume work by the Russian Doctor of Art History, the St. Petersburg Humanitarian University of Trade Unions Professor Viktor Vlasov (1995) "Styles in Art. Dictionary".

This publication contains exhaustive data on artistic schools, as well as particular trends, individual schools and creative associations that are known in the post-Soviet space. In addition, the author in his monographic work also interprets unconventionally understood styles, enterprising an attempt to designate within each style the semantic field of each term the most completely from the etymological, historical, geographical, interpretative viewpoints. 
Viktor Vlasov tried in his book, for a more complete understanding of the issue, to cite statements of well-known cultural figures on certain styles, stylistic schools and trends. The theoretical material in his research is supported by empirical tables that reveal the sequence of styles unfolding chronologically and synchronously (Vlasov, 1995).

The chresthomatic monograph by the German scientist Wilfrid Koch (2006) "Encyclopedia of Architectural Styles" is devoted to the study of style formation in architecture issues. In that research, the author covered the styles of ancient civilizations and large European historical styles that appeared almost synchronously on different continents, Eastern and Asian styles, style schools and trends, as well as microstyles common in certain countries of the world. This paradigmatically structured edition allows a comparison between the primary elements of individual architectural styles, including the period of late XIX-early XXI century, with the styles of design and fine art (Koch, 2006).

The publications regarding the Ukrainian design stylistics of the Soviet and post-Soviet period, are not numerous, an evident lack is felt as for fundamental and comprehensive ones acceptable for various types of design studying. The most significant research in this area has been developed by Valery Urenyov, Doctor of Architecture, Professor, Director of the Architectural and Art Institute of the Odessa National Academy of Building and Architecture, Honored Architect of Ukraine, full member of the Ukrainian Academy of Architecture, the International Academy of Architecture Professor.

In his monograph "Interiors of public catering enterprises" an attempt was made to characterize the design styles of the twentieth century second - third quarters in the field of design environment (Urenov, 1973). However, considering that half a century elapsed after the said work publishing, although this study did not lose its relevance, as for today it does not exhaustively cover the issues of stylistics in the interior design field, not to mention industrial, clothing, graphic design.

A separate attention to the problematic field «Notes about style in a design» has been paid by the Russian researcher Alexandr Grashin. In her article, this author made an attempt to arrange systematically the scattered information about individual styles in design, based on the experience of practical specialists (Grashin, 2018). However, if the history of styles in design is in such or another way traceable nowadays, the theory of styles in design and related areas of fine, decorative and applied arts and architecture still remains a little-studied problematic area thus needing for the available data verification. 
Results
of the
research

At the end of the nineteenth century, there was a need to more clearly separate styles in the field of fine art and architecture, since the role of a very important factor became attributed to the understanding of the stylistic unity of individual ensembles of productions that were developed taking into account the synthesis of arts.

The individual style trends that could cover not all, but some specific types of art and architecture at the same time, became important. Such, for example, were the decadence, symbolism and impressionism, which were not reflected in architecture, but did manifest themselves apart of the visual arts, in music and literature artistic spheres.

The universalism epoque gave rise to such phenomena as the creative work of, e.g., William Morris and the "Arts and Crafts" movement artists, who in their protodesign stood on the threshold of design discovery and sought to ensure that all art forms equally participated in the creation of a harmonious whole (Oppenheim, 1985, p. 1200).

Similar searches were carried out synchronously in the Viennese artistic workshops, the creation of several French and Polish artists, thanks to which the society realized the essence of the stylization issue (Stanislav Vyspyansky, Eugene Grasset and others). Similar searches have been taking place in Ukrainian art since the XIX and $X X$ centuries turn, that resulted in creative experiments of ornamentalist and generalists artists: Amvrosy Zhdakha, Mykhailo Zhuk, Vasyl Krichevsky, the search for "architectons" and avant-garde forms by Kazimir Malevych, Volodymyr Tatlin, Josephine Dindo, etc.

Further, since the Bauhaus period, the European art has been fertilized by the impulses of a new understanding of Vitruvius 'motto" Benefit. Endurance. Beauty". Therefore, in the Bauhaus movement, mathematical principles and engineering rigority were applied to fine arts, crafts and architecture (Weber, 2019, p. 174-175). This allowed experimenting with borderline and diffusive types of arts, crafts, design and architecture elements since the early beginning of modernism. However, the least studied in this regard was just the design, which was denied for a long time in the Soviet Union and Germany, where the legacy of the Bauhaus, representatives at the instigation of Adolf Hitler, was perceived for a long time with a negative coloring, as destructive and formal art (Markin, 2018).

Today, the environmental approach assumes understanding as retro styles (Ancient Greek, Ancient Roman, Byzantine, Georgian, Elizabethan, Victorian, and others); Oriental (Egyptian, Chinese, Turkish, Japanese, Persian style, Arab, Berber, Moorish, Indian, Mudejar, etc.), American (country, colonial style, etc.); reflections of the great historical European styles (in the range Romanesque - Modern style) the historicism as some eclectic style up to the appearance of design in the 1920-ies and the "designer" approach properly said (Bhaskaran, 2009). 
Among the latter trends in the $X X$ - early $X X \mid$ century first of all to be mentioned are the constructivism, minimalism, high-tech, glamour and fusion. And we can specifically and separately speak about biotech, eco-style, loft, shabby chic, Provence, deconstructivism, lounge, low-tech. In some studies, practical specialists also distinguish the Bauhaus (Bystrova, 2001, pp. 234-268).

To a large extent, all these styles are divided into classical, ethnic and modern classes, which mutually contact each other also intersecting with the styles of architecture (first of all, it concerns the interior, typical examples are Mediterranean, Scandinavian, Finnish, hygge, industrial, brutalism, grunge, rustic, bionic), fine and decorative arts (which are intertwined with industrial, graphic and fashion design); for example, functionalism, futurism, art deco, pop art, postmodernism, contemporary, boho, manga, pin-up, military, Mid - century modern and also correspond to the concepts of kitsch (a term that is ambiguously interpreted in different European countries) like vintage, retro, steampunk.

Today, studying the work of individual artists-painters of the second half of the twentieth century, e.g. the Transcarpathian school representatives (Adalbert Erdely, Anton Kashshay, Zoltan Sholtes, Volodymyr Mykyta), it is necessary to consider their formation peculiarities, taking into account the plein air in the Baltic States, where great importance was attached to the search for new European forms, coloristics in a postmodern key, design searches in art.

If we talk about the easel graphics in Ukraine from the 1920s to the 2000s, it also underwent huge transformations under the influence of design. Considering that the search for a balance between graphic design, propaganda art and advertising led to the appearance of compositions by El Lissitsky, Vasyl Ermylov, and the school of Mykhailo Boychuk in the twentieth century second quarter the Ukrainian graphic art undergone stylistic changes over the past hundred years, which influenced various genres: from ex-libris to ensembles of books with "reviving reality", social leaflets and posters, advertising on packaging and billboards.

It can be noted that in graphic design, at the same time, more than in other types, revealing is the connection with fine art, the domain, which artists sought to eliminate or integrate traditional elements into new styles (Kennedy, 1987, p. 375). So, during the $X X$ - beginning of the XXI century, this design type stylistics of passed the following stages: avant-garde, constructivism, cubism, suprematism and art-deco, social realism, then postmodernism, "the style of youthful dreams", polystylism, glamour.

At the same time, in industrial design, whose roots ascend to the modernism, during the designated period of time, there occurred clear infusive influences of functionalism, constructivism, avant-gardism, boychukism, socialist realism, Stalinist empire, 
Ukrainian soviet empire, neofunctionalism, neo-primitivism, neofolk style, polystylism, glamour (Shkolna, 2010). At that, the fashion design also reflected onto these styles, addressing these in recent years to boho, manga, military, western.

At the same time, the interior design echoed the pan-European classical, ethnic and modern trends, merge with these since the 1960s - 1970s, to say, the period there arose the opportunity to participate in international exhibitions, and especially after the "Iron Curtain" withdrawal.

\section{Scientific novelty and practical significance of the research}

Conclusions
The present study scientific novelty departs from the consideration of peculiar features of styles evolution in painting and graphics, architecture and various areas of design in Ukraine, that does mean industrial, graphic, clothing, interior design fields The points of mergers and contacts of these knowledge branches' stylistics are identified, general trends and intragroup ones for each type of artistic creativity are designated and characterized.

Fine art, architecture and design of Ukraine during the late XIX early XXI century period developed in a certain stylistic generality uniting the large European historical styles. Namely, these are: art nouveau, constructivism, art deco, avant-garde. However, each of these types of creative activity had its own specific development.

So, if eclecticism developed in architecture on an equal footing with the modern style, then functionalism, constructivism, the Stalinist empire, which was later replaced for half a century by the entire blocks of typical "depersonalised" buildings, which were replaced by fusion and high-tech with glass facades at the beginning of the XXI century, these trends were assimilated by interior design, organically interacting with architecture. In the studied design area, the minimalism, high-tech, classic, fusion, low-tech, shabby chic, provence, glamour, oriental stylizations became especially popular in Ukraine these recent years.

At the same time, in addition to the classics, fashion design has adapted sports-classic style, manga, country, western, military, boho, glamour, etc. over the past few decades.

At that, graphic design has adopted most of the stylistics traditions of fine art, partially merging in designer creative works with the styles of industrial design. Over the past hundred years, it has developed trends of modernism, avant-gardism, postmodernism, post-postmodernism, which fit into the following list: functionalism, constructivism, boychukism, art deco, socialist realism, Stalinist empire, Ukrainian soviet empire, neo-functionalism, neo-primitivism, neo-folk style, polystylism, glamour. 


\section{References}

Bhaskaran, L. (2009). Dizain i vremya: Stili i napravleniya v sovremennom iskusstve $i$ arkhitekture [Design and Timing. Styles and Trends in Contemporary Art and Architecture] (I. D. Golybina, Trans.). Art-Rodnik [in Russian].

Bystrova, T. Yu. (2001). Veshch', forma, stil'.. Vvedenie v filosofiyu dizaina [Thing, Form, Style... An Introduction to Design Philosophy]. Izdatel'stvo Ural'skogo universiteta [in Russian].

Grashin, A. A. (2018). Zametki o stile v dizaine [Notes on Style in Design]. Quality and Life, 4(20), 141-150 [in Russian].

Kennedy, J. (1987). The New Generation and Artistic Modernism in the Ukraine [Review of the book Studies in the Fine Arts: The Avant-Garde, by Myroslava M. Mudrak]. Slavic Review, 46(2), 375. https://doi.org/10.2307/2498984 [in English].

Koch, V. (2006). Entsiklopediya arkhitekturnykh stilei: Klassicheskii trud po evropeiskomu zodchestvu ot antichnosti do sovremennosti [Encyclopedia of Architectural Styles: A Classic Work on European Architecture from Antiquity to Modern Times] (L. I. Knysh, Trans.). Bertelsmann Lexikon Verlag [in Russian].

Markin, Yu. P. (2018). Iskusstvo Tret'ego Reikha. Arkhitektura. Skul'ptura. Zhivopis' [Art of the Third Reich. Architecture. Sculpture. Painting] (2nd ed.). BuksMArt [in Russian].

Oppenheim, J. (1985). Review work [Review of the book Redesigning the World: William Morris, the 1880s, and the Arts and Crafts, by Peter Stansky]. The American Historical Rewiew, 90(5), 1200. https://doi.org/10.1086/ahr/90.5.1200 [in English].

Shkolna, O. (2010). Hlamur yak novitnia kvaziestetychna katehoriia v systemi kryteriiv khudozhnosti suchasnoho tvoru z portseliany [Glamor as the Newest Quasi-Aesthetic Category in the System of Criteria of Art of a Modern Porcelain Work]. Art research of Ukraine, 11, 186-195 [in Ukrainian].

Urenov, V. P. (1973). Interiery pidpryiemstv hromadskoho kharchuvannia [Interiors of Public Catering Establishments]. Budivelnyk [in Ukrainian, in Russian]

Vlasov, V. G. (1995). Stili v iskusstve. Slovar'. Arkhitektura, grafika, dekorativno-prikladnoe iskusstvo, zhivopis'skul'ptura [Styles in Art. Dictionary. Architecture, Graphics, Arts and Crafts, Painting, Sculpture] (Vol. 1). Kol'na [in Russian].

Weber, N. F. (2019, August 6). The Bauhaus at 100: Science by Design. Nature, 572(7768), 174-175. https://doi.org/10.1038/d41586-019-02355-4 [in English]. 